\title{
An ecosystem box model for estimating the carrying capacity of a macrotidal shellfish system
}

\author{
O. Raillard ${ }^{1, *}$, A. Ménesguen ${ }^{2}$ \\ ${ }^{1}$ IFREMER, Unité de Recherche Ecosystèmes Aquacoles, BP 133, F-17390 La Tremblade, France \\ ${ }^{2}$ IFREMER, Direction de l'Environnement et de l'Aménagement Littoral, Laboratoire de Chimie et Modélisation des Cycles \\ Naturels, BP 70, F-29280 Plouzané, France
}

\begin{abstract}
An ecosystem model is presented for estimating the shellfish carrying capacity of Marennes-Oléron Bay (France). It incorporates physical and biological processes: horizontal transport of suspended matter, feeding and growth of the cultivated oyster Crassostrea gigas and primary production. The precision and consistency of the model are tested by comparing simulations to observed data. The model smoothes both spatial and temporal variability of suspended-matter concentrations but reproduces mean levels and seasonal cycles with some accuracy. Carrying capacity of the shellfish system is assessed by computing the sensitivity of oyster growth to oyster abundance. Model results clearly indicate a density dependence of oyster growth. When stock is adjusted from $20 \%$ to $200 \%$ of the present value, maximal dry weight of oysters shows a mean decrease of approximately $25 \%$. The spatial heterogeneity of the growth response is a consequence of the low level of primary production within the shellfish area. The hydrodynamic regime of the bay strongly controls the carrying capacity of the shellfish system: flushing time and available light energy are found to be 2 determining factors which prevent the phytoplankton from thriving in the bay; tidal currents ensure a fast renewal of food. Nevertheless, phytoplanktonic production accounts for a non-negligible part of food filtered by oysters and is identified as an important food source when stock level is low. The validity of the model is limited mainly by the present description of the physical transport of suspended and deposited matter.
\end{abstract}

KEY WORDS: Oyster farming $\cdot$ Carrying capacity $\cdot$ Ecological box model $\cdot$ Crassostrea gigas $\cdot$ Stock sensitivity

\section{INTRODUCTION}

Carrying capacity is a fundamental concept in shellfish culture. Following Incze et al. (1981) and Rosenberg \& Loo (1983), it corresponds to the ability of the system to support shellfish production. Mathematical tools are generally used to estimate carrying capacity. The complexity of the tools depends on the scientific requirements, the ecosystem considered and the availability of data.

Based on historical data, global models allow the overall production of a system to be represented as an empirical function of the biomass (Héral et al. 1986).

\footnotetext{
- Present address: CETIIS, 24 boulevard Paul Vaillant-Couturier, F-94200 Ivry-sur-Seine, France
}

This approach has the advantage of being simple and reliable. However, it provides a very restrictive picture of the carrying capacity since it does not account for potential variations of this capacity in space and time. In addition, there are empirical models which depict some aspects of the interrelationship between shellfish and food supply. The model developed by Incze et al. (1981) estimates the optimal size of a mussel culture from both seston concentration and water fluxes entering the system. In the model constructed by Wildish \& Kristmanson (1979), the growth potential of suspension-feeding macrobenthos is determined by the supply rate of ATP associated with advected seston. Smaal et al. (1986) correlate current velocity and shellfish biomass with seston depletion for different values of mussel bed length. In order to estimate the carrying capacity of their system, Carvet \& Mallet (1990) divide 
food supply, determined from measurements of tidal exchanges and food concentration, by food demand, estimated from in situ measurements of grazing.

Whatever their respective efficiency, the validity of these models is limited to restricted spatial and temporal scales, as they model neither the impact of shellfish culture on the overall dynamics of the system, nor the regeneration of food within the shellfish system, nor the spatial variability of both biological demand and physical characteristics of the system. When complex ecosystems are considered, a more explanatory, process-based model is needed (Héral et al. 1983a). The purpose of the present work is to refine the concept of carrying capacity by developing an ecosystem model which describes the physical and biological dynamics of a shellfish system.

Macrotidal estuaries are favourable areas for shellfish culture. Being protected from the turbulence of the sea, such estuaries offer good trophic conditions due to strong tidal currents which ensure an intensive renewal of food within the area. Nevertheless, the potential production of these areas is not unlimited. The case of Marennes-Oléron Bay, France, is a good illustration of this fact. Since its introduction into the bay in 1972, Japanese oyster Crassostrea gigas has shown a progressive reduction in its capacity for growth. The period of growth required for the oyster to reach a commercially valuable size has increased from 1.5 to 4 yr during the period 1972 to 1985 (Héral et al. 1986). At the same time, the mortality rate of the oyster has also increased. As shown by Héral et al. (1988), such physiological problems in C. gigas may have a trophic origin. By increasing the cultivated biomass, oyster-farmers may have reduced the food supply to the oysters.

Because of the economic consequences of this situation, the problem of estimating the carrying capacity of Marennes-Oléron Bay has become a priority. Bacher (1989) has developed a first model for this which couples the feeding behaviour of Crassostrea gigas and the physical transport of food. It reveals density dependence of oyster growth and strong intra-specific competition. However, the model is based on the assumption that renewal of food by primary production is negligible when compared to the inputs by tidal currents at the ocean boundary. On this basis, the 'stock/ growth' relationship computed by Bacher's model infers that sensitivity of the carrying capacity to primary production does not depend on stock level. This assumption is reasonable for small changes in stock level but may become unreasonable when large variations are considered.

The present model is designed to incorporate feeding behaviour and growth of oysters, primary production and physical transport in the same spatial and temporal framework. The goal is to establish relations between oyster growth and biomass and also to point out the physical and biological processes which determine the carrying capacity of the bay.

The study is composed of 2 parts. First, the consistency and precision of the model are assessed by comparing calculations to the data. Second, the model is used to quantify the sensitivity of oyster growth to oyster biomass.

\section{MATERIAL AND METHODS}

General description of the bay. Marennes-Oléron Bay is situated in southwest France. It is delimited by Oléron Island on its western side and by the continental coast on its eastern side (Fig. 1). Water exchange with the sea occurs in the north through the narrows of Antioche and in the south through the narrows of Maumusson. The area of the bay is $200 \mathrm{~km}^{2}$ and its mean depth is about $5 \mathrm{~m}$, with an average of $10 \mathrm{~m}$ in the

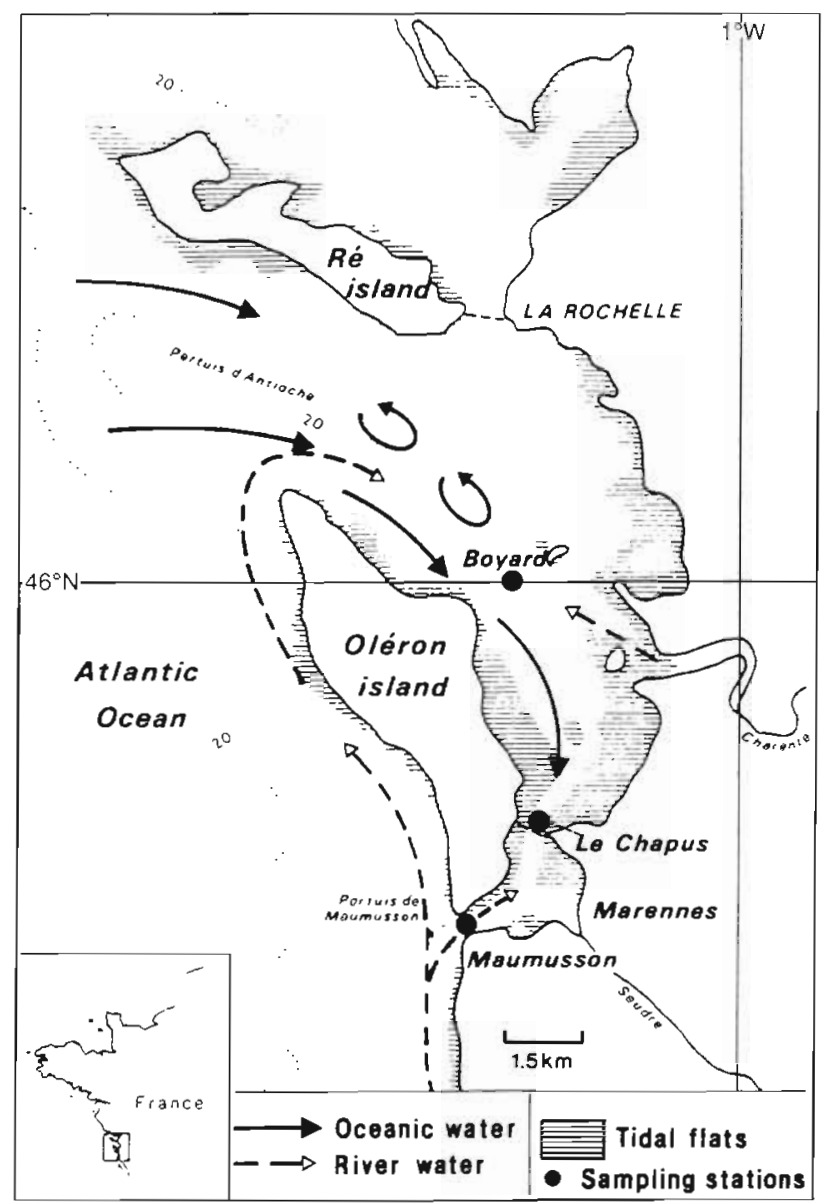

Fig. 1 Marennes-Oléron Bay, France, showing the main circulation features. Isobaths in meters 
north. The bay is a dynamic environment with a tidal range up to $5 \mathrm{~m}$. The local hydrodynamic regime is regulated mainly by tidal currents, resulting in a southward residual transport of the water masses. Residence time of a water parcel in the bay is between 5 and $10 \mathrm{~d}$, depending on tide and meteorological conditions. The River Charente is the major source of freshwater input into the bay. Although river flow is negligible (1\%) in comparison to oceanic inflow $(99 \%)$, it can be an important source of nutrients, thus increasing primary production (Ravail et al. 1988). During periods of flooding, the waters of Gironde enter the bay (Dechambenoy et al. 1977) and have been shown to increase nutrient levels significantly.

Crassostrea gigas is cultivated in the bay. Its estimated biomass is approximately $110000 \mathrm{t}$ and annual biological production can rise up to $35000 \mathrm{t}$ (A. Bodoy pers. comm.). This latter value marks MarennesOléron Bay as one of the most productive areas for oysters in the northeast Atlantic.

Ecosystem model. Physical sub-model: A hydrodynamic model was developed (Anon. 1979) to calculate vertically averaged current velocity and direction throughout the bay. Considering the vigorous hydrodynamic regime and the shallow bathymetry of the bay, it can be assumed that the water column is vertically homogeneous. In this model, tidal forcing is the only factor determining water circulation.

Ecosystem models rarely require the spatial and temporal resolution needed for accurate hydrodynamic calculations (Bird \& Hall 1988). Following Chen \& Smith (1979), Radford \& Joint (1980), Lindeboom et al. (1988) and Bacher (1989), the hydrodynamic outputs of the physical model were averaged over time and space, resulting in an advection-dispersion 'box model' that drives the horizontal transport of dissolved and particulate matter within Marennes-Oléron Bay. The procedure for calculating spatial and temporal distribution of the parameters of the advection-dispersion model using the outputs of the hydrodynamic model is detailed in Bacher (1989). Fluxes between contiguous boxes are integrated over the tidal period $(12 \mathrm{~h}$ $25 \mathrm{~min}$ ), so only tidal residual circulation is considered, and it is assumed that biological processes are not affected by higher frequency variations of environmental parameters. The alternation between spring and neap tides is simulated by linear interpolation between 'spring tide' and 'neap tide' velocity fields alternating every $7.3 \mathrm{~d}$.

The geographic position of the model is determined so that one can assume that the calculations will not influence the boundary conditions. Three boundaries are considered: the northern and southern boundaries (L1) receive the same oceanic inputs, and the River Charente enters the bay through the eastern boundary
(L2). Elementary cells of the hydrodynamic model were aggregated into boxes in order to match as far as possible the physical and biological gradients in the bay including those of: current velocity and direction, salinity (due to Charente Estuary), and oyster distribution (flooding areas/gullies). The amplitude of the tidal excursion, which is responsible for water mixing, determines the mean geographic extent of the boxes. The segmentation of Marennes-Oléron Bay is shown in Fig. 2. For box volume computation, only marine area is taken into account.

When interaction with biological processes is absent, the concentration of seston $C_{i}$ in Box $i$ over time $t$ is calculated by the following equation:

$$
\mathrm{V}_{i} \cdot \frac{\mathrm{dC}_{j}}{\mathrm{dt}}=-\mathrm{A}_{i j} \cdot \mathrm{C}_{i}+\sum_{j \neq i}^{\mathrm{n}} \mathrm{A}_{1 j} \cdot \mathrm{C}_{j}+\sum_{j \neq 1}^{\mathrm{n}} \mathrm{D}_{1 j} \cdot\left(\mathrm{C}_{j}-\mathrm{C}_{i}\right)
$$

where $\mathrm{n}$ is the total number of boxes, $\mathrm{V}_{i}$ is the volume of Box $i, \mathrm{~A}_{\mu j}$ is the advective flow coming out of Box $i$,

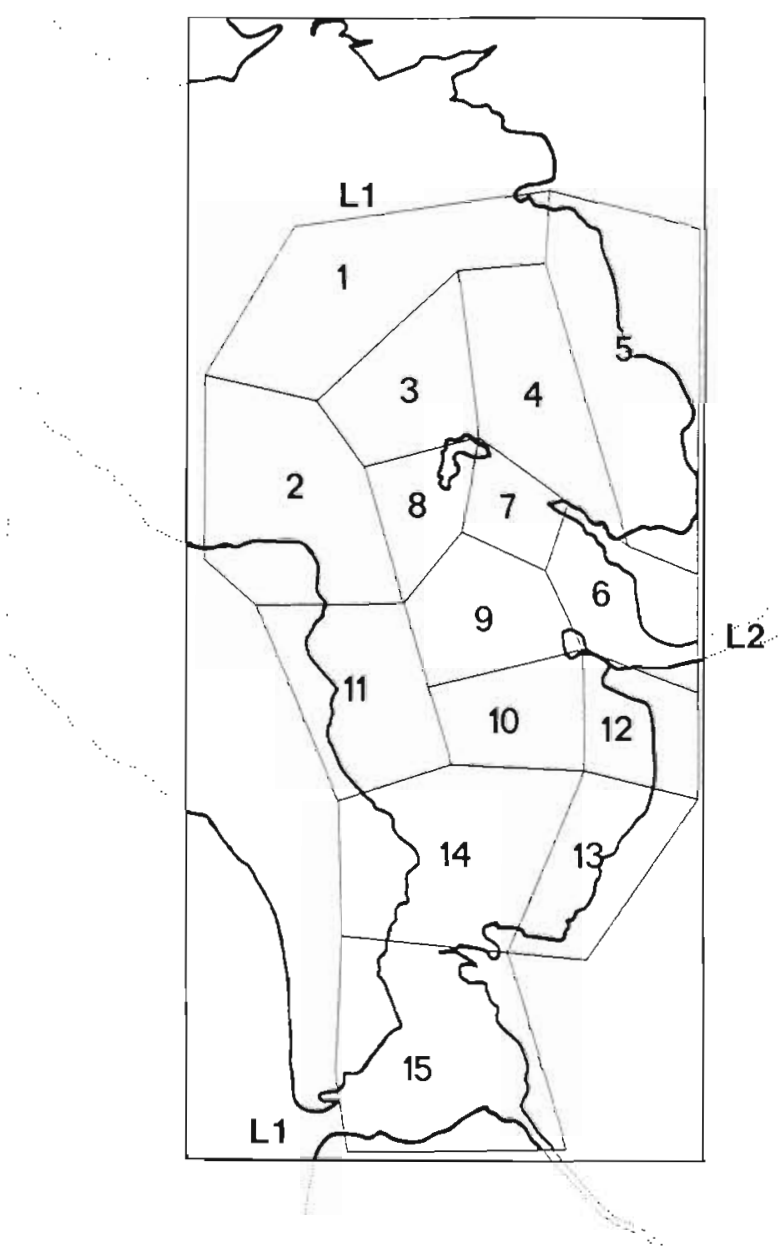

Fig. 2. Division of Marennes-Oléron Bay into model compartments (i.e. boxes); the limits of the box model are: L1, oceanic limits; L2, river limit 


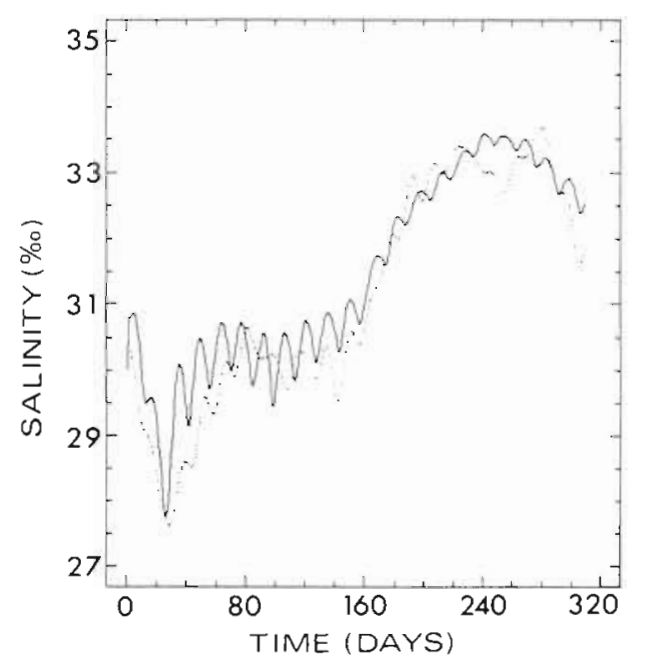

Fig. 3. Comparison of observed (-) and simulated (..) salinity in Box 14

$\mathrm{A}_{l j}$ is the advective flow entering from Box $j$ into Box $i$, and $\mathrm{D}_{i j}$ is the dispersive flow between Box $i$ and Box $j$.

Dispersive flows $D_{i j}$ are used to calibrate the transport box model by fitting simulated salinity to observed values collected in the middle of the bay during $1 \mathrm{yr}$. Satisfactory agreement between simulated and observed data can be obtained (Fig. 3).

The transport equation is solved by a first upward differencing scheme (Bird \& Hall 1988).

Biological sub-model: Because inorganic $N$ is known to be the primary limiting nutrient for phytoplanktonic growth in Marennes-Oléron Bay (Héral et al. 1983b), the model simulates the nitrogen cycle in the water and the sediment. State variables and their relationships are shown in Fig. 4. The system of differential equations and the functions used in the model are detailed in Tables 1 \& 2 respectively.

Driving variables are temperature $(T)$, intensity of photosynthetically active radiation (I) and sea state (Turb). The seasonal cycle of temperature is modelled by adjusting a sinusoidal curve to the data collected in the bay (see Table 2). Solar radiation at the sea surface is derived from daily insolation observations using the Brock (1981) method. Sea state is a synthetic variable which drives vertical exchanges of particulate matter, with a trend to erosion in winter and to sedimentation in summer (Sornin 1981). Accordingly, sea state is described by a sinusoidal function of time (Table 2).

Processes concerning feeding behaviour and growth of individual oysters have been detailed by Raillard et al. (1993). Suspended particulate organic matter (SPOM) and phytoplankton are the food source of

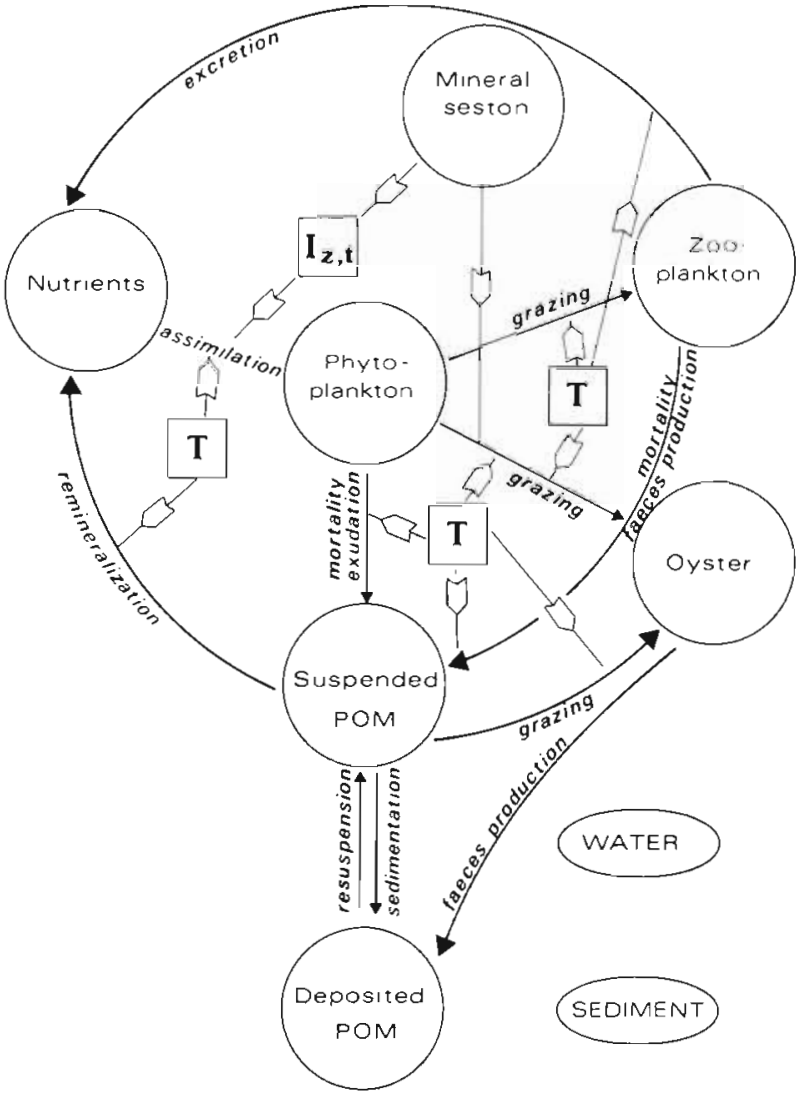

Fig. 4. Process flow diagram for the model. $I_{z, t}$ : light at depth $z$ and time $t_{i} T$ : temperature; POM: particulate organic matter

Japanese oysters (Bayne et al. 1976, Soniat et al. 1984). Faeces, phytoplankton and SPOM supply the benthic POM (Kautsky \& Evans 1987). As a first approximation, we assume that pseudofaeces presence does not affect the accessibility of food to oysters (Newell \& Jordan 1983). The demographic structure of the oyster population is represented by 2 age classes: the first class includes the $1 \mathrm{yr}$ old oysters, and the second includes 2 and 3 yr old oysters. The temporal evolution of the numbers of the 2 age classes is driven by a first order law (Bacher 1989).

For the other components of the ecosystem, the equations of the biological sub-model are presented in Table 2. The effect of temperature on various rates is considered as being exponential over the usual range of sea temperature observed in Marennes-Oléron Bay. Phytoplanktonic growth is reduced by nutrient limitation according to a Michaelis-Menten hyperbola and by light energy according to the Steele (1962) function. The extinction coefficient is linearly dependent on seston concentration (Cloern 1987). In our model, phytoplankton settling on the bottom is considered a natural mortality process, with a rate linearly depending on 
the nutrient limitation factor (Eppley et al. 1967). Grazing of phytoplankton and detrital matter by zooplankton is modelled by an Ivlev curve; grazing occurs above a threshold concentration and remains null under this threshold (Parsons et al. 1967, Frost 1972). Zooplanktonic assimilation efficiency is an exponentially decreasing function of the weight of ingested organic matter (Gaudy 1974). Zooplankton excretion rate is the higher of 2 terms: a constant fraction of the assimilated food (Corner et al. 1967) or basal excretion rate as a function of temperature. Nitrogen remineralization is governed by a first order law. Sedimentation and resuspension, which link detrital organic matter in the water and the sediment, are driven by the external variable Turb. Values of the parameters were set according to values currently used in similar models (Table 3).

Coupling the physical and the biological submodels: The transport model does not account for specific meteorological processes such as winds and storms (Bacher 1989). Accordingly, the ecological model uses data corresponding to an average year.
Daily concentrations at the box boundaries for all the pelagic variables are calculated by a linear interpolation of monthly averages [see Bacher (1989) for the sampling strategy used in Marennes-Oléron Bay]. As a result, the annual cycle at the boundaries is free of accidental perturbations (Fig. 5).

As the model was revealed to be insensitive to initial values of pelagic variables (which could be determined from in situ measurements), in a first approximation, initial values of benthic nitrogen stocks (for which there are no data available) are set equal to zero. The initial number of oysters in each box is determined according to an estimate based on a sampling survey in 1984 (Bacher et al. 1986). Boxes 10, 11, 13, 14 and 15 contain oysters of both age classes.

The differential equations for the coupled physical and biological sub-models are integrated using a fourth order Runge-Kutta time step varying method.

Simulations: For the pelagic variables, observed values are presented using the same method as that used for the boundaries. Only 2 years of data are available for oyster weight. Assuming that the oyster growth

Table 1. System of differential equations used in the model. Hwat: average water depth of the box. Other variables defined in Table 2

Dissolved mineral nitrogen $\left(\mu \mathrm{mol} \mathrm{N}^{-1}\right)$

$$
\frac{\mathrm{dNMIN}}{\mathrm{dt}}=- \text { Pgrowth } \cdot \text { NPHY }+ \text { Nremin } \cdot \text { NDET }+ \text { Zexcr } \cdot \text { NZOO }
$$

Phytoplankton nitrogen ( $\mu$ mol $\mathrm{N}^{-1}$ )

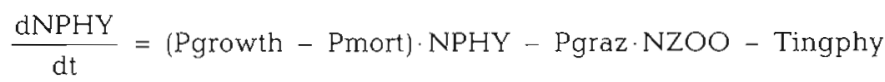

Zooplankton nitrogen $\left(\mu \mathrm{mol} \mathrm{N} \mathrm{^{-1 } )}\right.$

$\frac{\mathrm{dNZOO}}{\mathrm{dt}}=($ Pgraz $\cdot$ asszoo - Zexcr - Zmort $) \cdot \mathrm{NZOO}$

Detrital nitrogen ( $\left.\mu \mathrm{mol} \mathrm{N}{ }^{-1}\right)$

$\frac{\mathrm{dNDET}}{\mathrm{dt}}=$ Pmort $\cdot$ NPHY $+($ Zegest + Zmort $) \cdot$ NZOO + Nresusp $\frac{\text { NBEN }}{\text { Hwat }}-\left(\frac{\text { Nsedim }}{\text { Hwat }}+\right.$ Nremin $) \cdot$ NDET

Benthic nitrogen ( $\mathrm{mmol} \mathrm{N} \mathrm{m}^{-2}$ )

$\frac{\mathrm{dNBEN}}{\mathrm{dt}}=$ Nsedim $\cdot$ NDET - Nresusp $\cdot$ NBEN $+($ Tfecphy + Tfecdet $) \cdot$ Hwat

Oyster dry weight $\left(\mathrm{J}_{\text {ind }}{ }^{-1}\right)$

$\frac{\mathrm{dOys}}{\mathrm{dt}}=\mathrm{Sfg}-$ Spawn

Oyster number for the $k$ th age class

$\frac{\mathrm{dSto}_{k}}{\mathrm{dt}}=\mathrm{Hmort}_{k} \cdot \mathrm{Sto}_{k}$

Mineral seston (mg dry wt $1^{-1}$ )

$\frac{\mathrm{dSES}}{\mathrm{dt}}=0$ 
Table 2. Equations of the biological submodel. VolB: box volume. Other variables defined in Tables $1 \& 3$

\begin{tabular}{|c|c|c|}
\hline Quantity & Meaning & Formula \\
\hline Pgrowth & Phytoplankton growth rate & $\mu \max \cdot f(\mathrm{I}) \cdot f(\mathrm{~T}) \cdot f(\mathrm{~N})$ \\
\hline$f(\mathrm{~T})$ & Temperature effect & $e^{k t \cdot T}$ \\
\hline$f(\mathrm{I})$ & Light effect on phytoplankton & $\int_{0}^{24} \int_{z \min }^{z \max } \frac{I_{z, t}}{I_{o p t}} \cdot e^{\left(1-\frac{I_{z, t}}{l o p t}\right)} d z d t$ \\
\hline $\mathrm{I}_{z, \mathrm{l}}$ & Light at depth $z$ and time $t$ & $I_{\text {surf }, t} \cdot e^{-k l \cdot z}$ \\
\hline $\mathrm{kl}$ & Light extinction coefficient & akt $\cdot S E S+a k 0$ \\
\hline$f(\mathrm{~N})$ & Nitrogen limitation & $\frac{\mathrm{NMIN}}{\mathrm{NMIN}+\mathrm{kN}}$ \\
\hline Pmort & Phytoplankton mortality rate & mnphy $f(\mathrm{~N})+\operatorname{mxphy} \cdot[1-f(\mathrm{~N})]$ \\
\hline Pgraz & Zooplankton grazing rate & $\operatorname{Imax} \cdot f(T) \cdot\left(1-\mathrm{e}^{-\mathrm{kz} \cdot \max \left(0 . \mathrm{NPH} Y-\mathrm{PO}_{0}\right)}\right)$ \\
\hline asszoo & Zooplankton assimilation efficiency & $\operatorname{assmax} \cdot e^{-k a \cdot P g r a ̆ z}$ \\
\hline Zegest & Zooplankton egestion rate & $(1-\operatorname{asszoo}) \cdot$ Pgraz \\
\hline Zexcr & Zooplankton excretion rate & $\max [$ Pgraz'asszoo'excrphy, excrzoo $f(T)]$ \\
\hline Zmort & Zooplankton mortality rate & $m z o o \cdot f(T)$ \\
\hline Ting[phy,det] & Oyster ingestion & $\sum_{k=1}^{\mathrm{nc}} \sum_{i=1}^{\operatorname{Sto}_{k}} \operatorname{Ing}[\mathrm{PHY}, \mathrm{DET}]_{k i} \cdot \frac{1}{\operatorname{VolB}}$ \\
\hline Ing $\left[\right.$ phy, det $\left.\right|_{k j}$ & Individual oyster ingestion & $F \cdot N[$ phy, det $] \cdot(1-P F)$ \\
\hline F & Individual oyster filtration rate & $F \max \cdot e^{k f \cdot \min (0 . T s e s-S E S)} \cdot W^{b f}$ \\
\hline W & Oyster dry weight in grams & Oys-pj \\
\hline $\mathrm{PF}$ & Proportion rejected as pseudo-faeces & PFo $\cdot\left(1-\mathrm{e}^{\mathrm{kp} 1 \cdot \min (0, c 1-C t)}\right)+(1-\mathrm{PFO}) \cdot\left(1-\mathrm{e}^{\mathrm{kp} 2 \cdot \min (0, \mathrm{c} 2-C t}\right)$ \\
\hline $\mathrm{Ct}$ & Standardized oyster consumption & $\frac{F \cdot[\mathrm{SES}+(\mathrm{NPHY}+\mathrm{NDET}) \cdot \mathrm{pN}]}{W^{\mathrm{bi}}}$ \\
\hline Tfec[phy,det] & Oyster egestion & Ting[phy,det $] \cdot(1$ - assoys $)$ \\
\hline assoys & Oyster assimilation efficiency & $\mathrm{aet} \cdot \mathrm{T}+\mathrm{ae} 0$ \\
\hline Sfg & Individual oyster 'scope for growth' & assoys $\cdot\left(\right.$ Ingphy $_{k \cdot} \cdot$ ephy + Ingdet $_{k i} \cdot$ edet $)-\mathrm{R} \cdot \mathrm{eO}_{2}$ \\
\hline $\mathrm{R}$ & Individual oyster respiration & $(\mathrm{art} \cdot \mathrm{T}+\mathrm{arO}) \cdot \mathrm{W}^{\mathrm{br}}$ \\
\hline Spawn & Individual oyster spawning & $\left(a p \cdot O y s^{b p}\right)^{1 / d p}$ \\
\hline Nremin & Organic nitrogen mineralization & $\operatorname{minazote} \cdot f(\mathrm{~T})$ \\
\hline Nsedim & Organic nitrogen sedimentation rate & sedmin-Turb + sedmax $(1-$ Turb $)$ \\
\hline Nresusp & Benthic nitrogen resuspension & resmin $\cdot$ Turb + resmax $\cdot(1-$ Turb $)$ \\
\hline Turb & Sea state & $1+\sin \left(\frac{2 \pi}{365} \cdot(t-140)\right)$ \\
\hline t & Julian days & 2 \\
\hline
\end{tabular}

curve follows a general pattern that does not change from one year to another, these data may be used to test the ability of the model to simulate oyster weight evolution.

To study the relationship between oyster growth and the total biomass under cultivation, several 1 yr long simulations were performed, using initial values of oyster abundance scaled by a factor varying from 0.2 to 2 , in each box and for both age classes. The maximal dry weight reached by oysters in the different boxes was then plotted against the corresponding factoradjusted initial stocks. 


\section{RESULTS}

\section{Standard simulation}

Unfortunately, the model failed to simulate accurately the wintering levels of nitrate in Box 8 (Fig. 6). However, this discrepancy between model and data does not call into question the consistency of the biological sub-model, since winter variations of nitrate have little influence on phytoplanktonic growth. During the rest of the year, calculated values stayed closer to the measured ones. In the middle of the bay (Box 14), simulation of nitrate represented with some accuracy the overall average concentration and its seasonal cycle (Fig. 6).

Simulation of mineral seston in Boxes 8 and 14 followed the mean trend of observed concentrations. Simulated changes in phytoplankton biomass in Box 8

Table 3. Values of the parameters used in the biological sub-model

\begin{tabular}{|c|c|c|}
\hline Parameter & Meaning & Value \\
\hline \multicolumn{3}{|c|}{ Phytoplankton } \\
\hline umax & Maximal growth rate at $0^{\circ} \mathrm{C}$ & $0.5 \mathrm{~d}^{-1}$ \\
\hline $\mathrm{kN}$ & Half saturation constant for $\mathrm{N}$ limitation & $1.5 \mu \mathrm{mol} \mathrm{l} \mathrm{l}^{-1} \mathrm{~N}$ \\
\hline lopt & Optimal light intensity & $70 \mathrm{~W} \mathrm{~m}^{-2}$ \\
\hline $\mathrm{akt}$ & Slope of the kl curve vs SES & $0.06 \mathrm{~m}^{2} \mathrm{~g}^{-1}$ dry wt \\
\hline $\mathrm{ak} 0$ & Intercept of the kl curve vs SES & $0.17 \mathrm{~m}^{-1}$ \\
\hline $\mathrm{kt}$ & Temperature coefficient & $0.07^{\circ} \mathrm{C}^{-1}$ \\
\hline mxphy & Maximal mortality rate & $0.1 \mathrm{~d}^{-1}$ \\
\hline mnphy & Minimal mortality rate & $0.01 \mathrm{~d}^{-1}$ \\
\hline ephy & Energy equivalent & $2.86 \mathrm{~J}_{\mu \mathrm{mol}^{-1} \mathrm{~N}}$ \\
\hline \multicolumn{3}{|c|}{ Zooplankton } \\
\hline$r \max$ & Maximal growth rate at $0^{\circ} \mathrm{C}$ & $0.25 \mathrm{~d}^{-1}$ \\
\hline $\mathrm{kz}$ & Ivlev's constant & $0.121 \mu \mathrm{mol}^{-1} \mathrm{~N}$ \\
\hline $\mathrm{ka}$ & Assimilation efficiency exponent & 0.5 \\
\hline Po & Ivlev's grazing threshold & $0.5 \mu \mathrm{mol} \mathrm{N} l^{-1}$ \\
\hline assmax & Maximal assimilation efficiency & 0.6 \\
\hline excrzoo & Excretion rate at $0^{\circ} \mathrm{C}$ & $0.025 \mathrm{~d}^{-1}$ \\
\hline excrphy & Excreted ratio of the assimilated food & $0.15 \mathrm{~d}^{-1}$ \\
\hline mzoo & Mortality rate at $0^{\circ} \mathrm{C}$ & $0.035 \mathrm{~d}^{-1}$ \\
\hline \multicolumn{3}{|l|}{ Nitrogen } \\
\hline minazote & Mineralization rate at $0^{\circ} \mathrm{C}$ & $0.05 \mathrm{~d}^{-1}$ \\
\hline sedmin & Minimal sedimentation velocity of detrital matter & $1 \mathrm{~m} \mathrm{~d}^{-1}$ \\
\hline sedmax & Maximal sedimentation velocity of detrital matter & $2.5 \mathrm{~m} \mathrm{~d}^{-1}$ \\
\hline resmin & Minimal resuspension rate of detrital matter & $0.02 \mathrm{~d}^{-1}$ \\
\hline resmax & Maximal resuspension rate of detrital matter & $0.2 \mathrm{~d}^{-1}$ \\
\hline $\mathrm{pN}$ & $\mu \mathrm{mol} N$ to $\mathrm{mg}$ dry wt conversion & $0.4 \mathrm{mg}$ dry wt $\mu \mathrm{mol}^{-1} \mathrm{~N}$ \\
\hline edet & Energy equivalent & 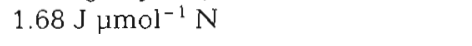 \\
\hline \multicolumn{3}{|l|}{ Oyster } \\
\hline Fmax & Maximal filtration rate & $48 \mathrm{l} \mathrm{d}^{-1} \mathrm{~g}^{-1}$ dry wt \\
\hline $\mathrm{kf}$ & Filtration exponent for clogging & 0.07 \\
\hline Tses & Clogging threshold & $200 \mathrm{mg} \mathrm{l}^{-1}$ \\
\hline bf & Allometric exponent of filtration & 0.4 \\
\hline PFo & Pseudo-faeces production step & 0.4 \\
\hline $\mathrm{kp} 1, \mathrm{kp} 2$ & Pseudo-faeces exponents & $0.15,0.01$ \\
\hline $\mathrm{c} 1, \mathrm{c} 2$ & Pseudo-faeces thresholds & $120,2400 \mathrm{mg}$ dry wt $\mathrm{d}^{-1} \mathrm{~g}^{-1}$ dry wt \\
\hline aet & Slope of assimilation curve vs temperature & $0.033^{\circ} \mathrm{C}^{-1}$ \\
\hline aeo & Intercept of assimilation curve vs temperature & 0.033 \\
\hline art & Slope of respiration curve vs temperature & $0.768 \mathrm{ml} \mathrm{O}_{2} \mathrm{~d}^{-1} \mathrm{~g}^{-1}$ dry wt ${ }^{\circ} \mathrm{C}^{-1}$ \\
\hline ar0 & Intercept of respiration curve vs temperature & $-0.528 \mathrm{ml} \mathrm{O}_{2} \mathrm{~d}^{-1} \mathrm{~g}^{-1}$ dry wt \\
\hline br & Allometric exponent of respiration & 0.7 \\
\hline ap & Proportionality constant of spawning & $0.57 \times 10^{-2}$ \\
\hline bp & Allometric exponent of spawning & 1.28 \\
\hline $\mathrm{dp}$ & Spawning period & 58 \\
\hline Hmort $_{1,2}$ & Mortality rate for the first and second age class & $1.5 \times 10^{-3}, 3.4 \times 10^{-4} \mathrm{~d}^{-1}$ \\
\hline $\mathrm{eO}_{2}$ & Energetic conversion of oxygen & $20 \mathrm{~J} \mathrm{ml}^{-1} \mathrm{O}_{2}$ \\
\hline pj & Mass conversion of energy & $0.05 \mathrm{~g}$ dry wt $\mathrm{kJ}^{-1}$ \\
\hline nc & Number of age classes & 2 \\
\hline
\end{tabular}




\section{L1}
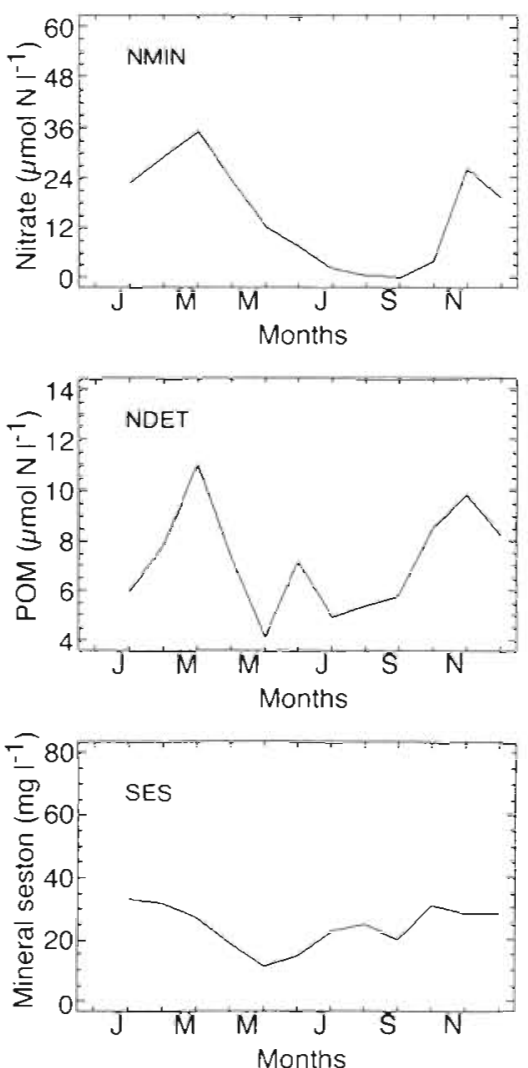
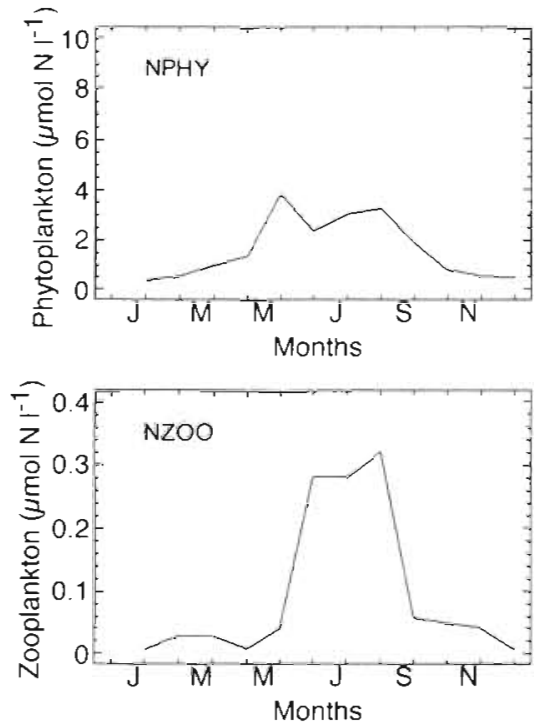

L2
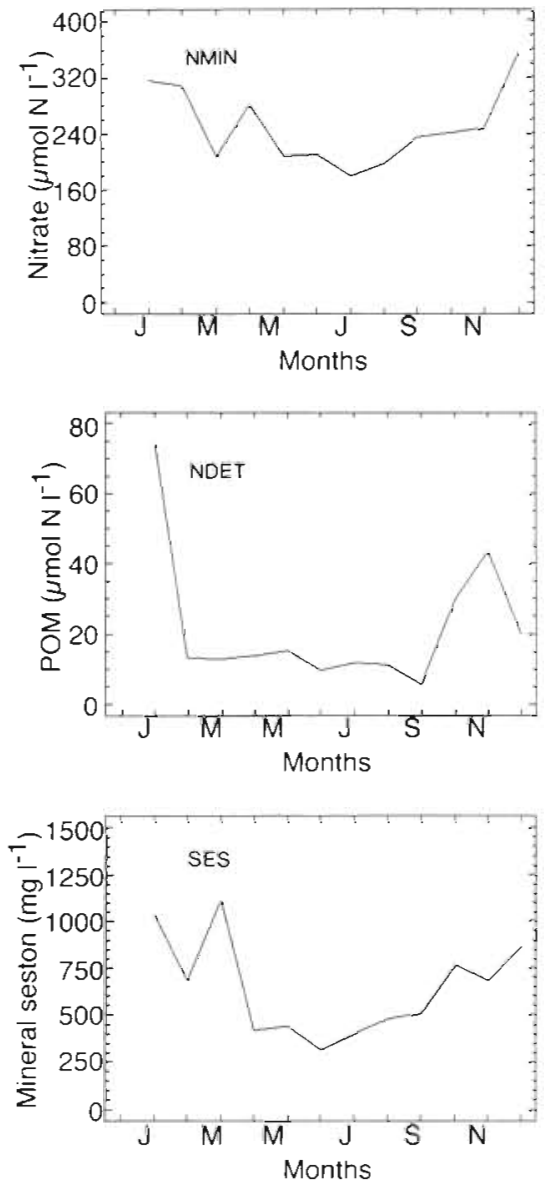

Fig. 5. Temporal distribution of the pelagic variables at the boundaries of the box model. L1: oceanic limits; L2: river limit

corresponded reasonably well to the data in winter and spring but did not reproduce the secondary bloom in summer. In Box 14, calculated phytoplankton biomass showed a satisfactory agreement with the mean observed values. However, the model slightly underestimated concentrations during winter and spring blooms and predicted a high value in summer. In the estuary area (Box 6), the model largely underestimated the phytoplankton biomass throughout the year (Fig. 6).

The spring/neap tidal variability observed for the pelagic components was poorly simulated by the model. If one omits the simulation of nitrate in Box 14, the model either smoothed the oscillations (see mineral seston in the center of the bay, Box 14) or did not simulate them at all (see phytoplankton biomasses in Boxes 6 and 14, or nitrate, phytoplankton and mineral seston in Box 8).

The simulated oyster growth curve (Fig. 7) followed a pattern similar to the observed one: maximal growth in spring, stabilization during winter and autumn and a large loss in summer for the second age class due to spawning. This indicates clearly that oyster growth is determined more by seasonal changes in the environment than by the spring/neap variability, which was poorly simulated by the model.

\section{Sensitivity of oyster growth to oyster stock}

Results indicated a global influence of stock level on oyster growth. When the oyster stock was divided by 5 , the maximal dry weight of oysters was increased on average by $14 \%$; when the oyster stock was multiplied by 2 , the maximal dry weight was reduced by $12 \%$. Another global feature of this result is the non-linear nature of the growth sensitivity to stock level. This form of growth density dependence has been observed for historical data of Marennes-Oléron Bay (Héral et al. 1986).

Oyster growth sensitivity was also dependent on the geographical location of the oysters. As shown in Fig. 8, the growth of oysters located in the middle and south of the bay (Boxes 13,14 and 15) appears to be more sensitive to stock level than the growth of oysters located in the north (Boxes 10 and 11). Because of 


\section{Box 6}

Charente estuary
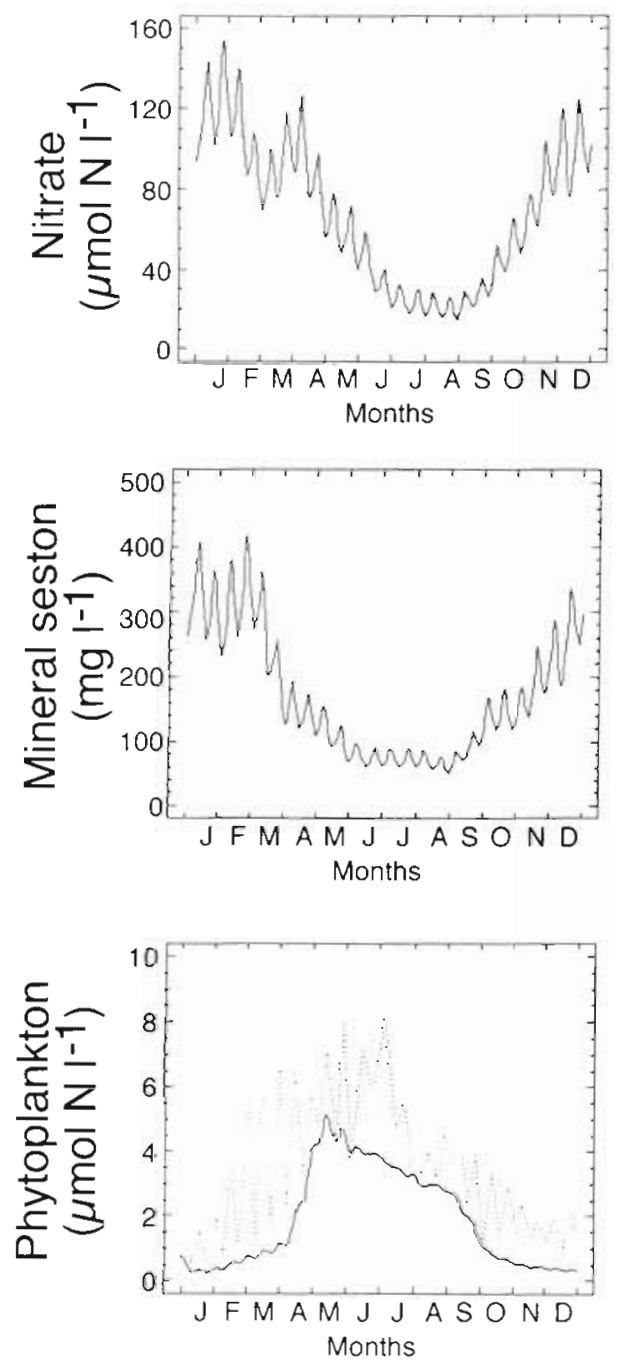

Box 8 Boyard
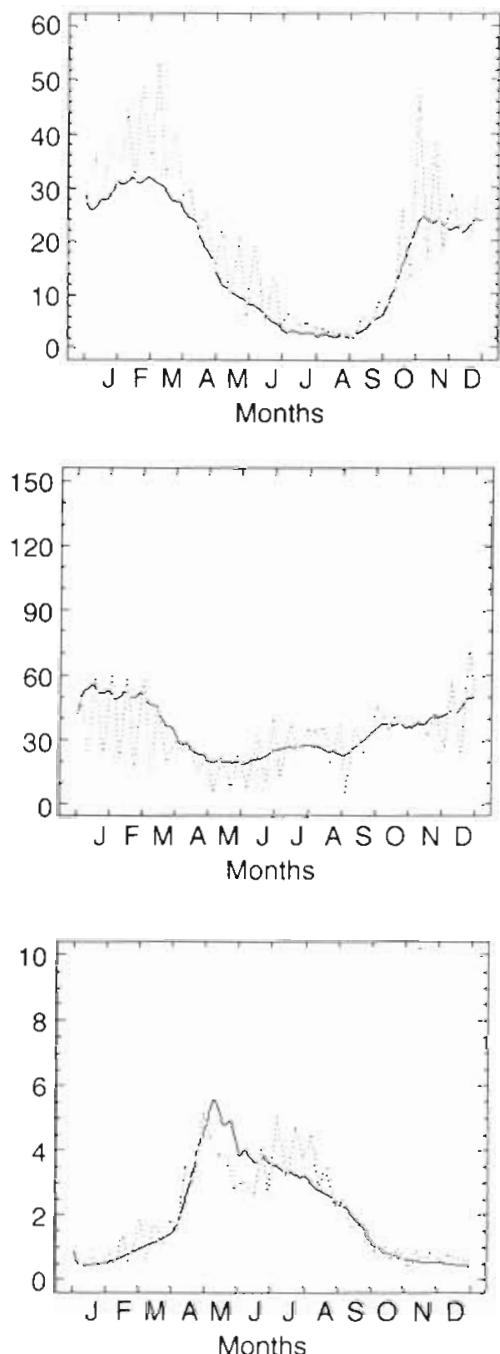

Box 14

Chapus
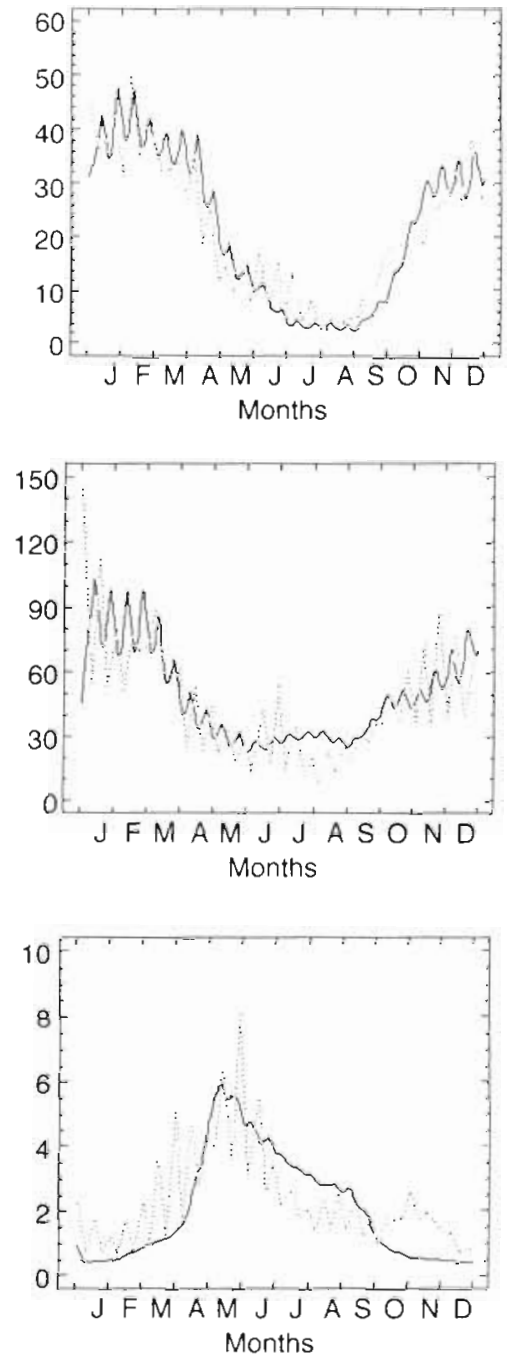

Fig. 6. Simulated (-) and observed () pelagic variables in Boxes 8,6 and 14

the north-south flux of food through the bay, the growth of oysters in the central area (Boxes 13 and 14) is determined not only by the local stock of oysters, but also by those oysters found in the northern area (Boxes 10 and 11), which previously deplete the food. The lower sensitivity of oysters located further south (Box 15), compared to those in Boxes 13 and 14, is actually due to the proximity of the southern oceanic boundary. The food supply coming from this boundary counterbalances the depletion of food coming from the northern area.

The variation of total oyster stock modified the gradient of carrying capacity among the different boxes. When stocks were low $(<100 \%)$, Boxes 13,14 and 15 exhibited the highest trophic capacity, whereas the northern boxes (10 and 11) provided the best oyster growth for large values of stock (>100\%).

Thus, the total oyster production of the bay depends on 2 inversely correlated parameters: initial oyster density, and individual growth performance. When the initial stock is increased, production tends to increase, whereas growth slows down. Ultimately, the negative influence of the increasing stock on individual growth leads to a relative stabilization of total production. Total production is reduced by $44 \%$ when the oyster stock is divided by 2 (relative to the present situation) yet is increased by only $28 \%$ when the stock level is multiplied by 1.5 . So, the relative gain in production obtained by increasing oyster abundance tends to vanish at high stock levels. 


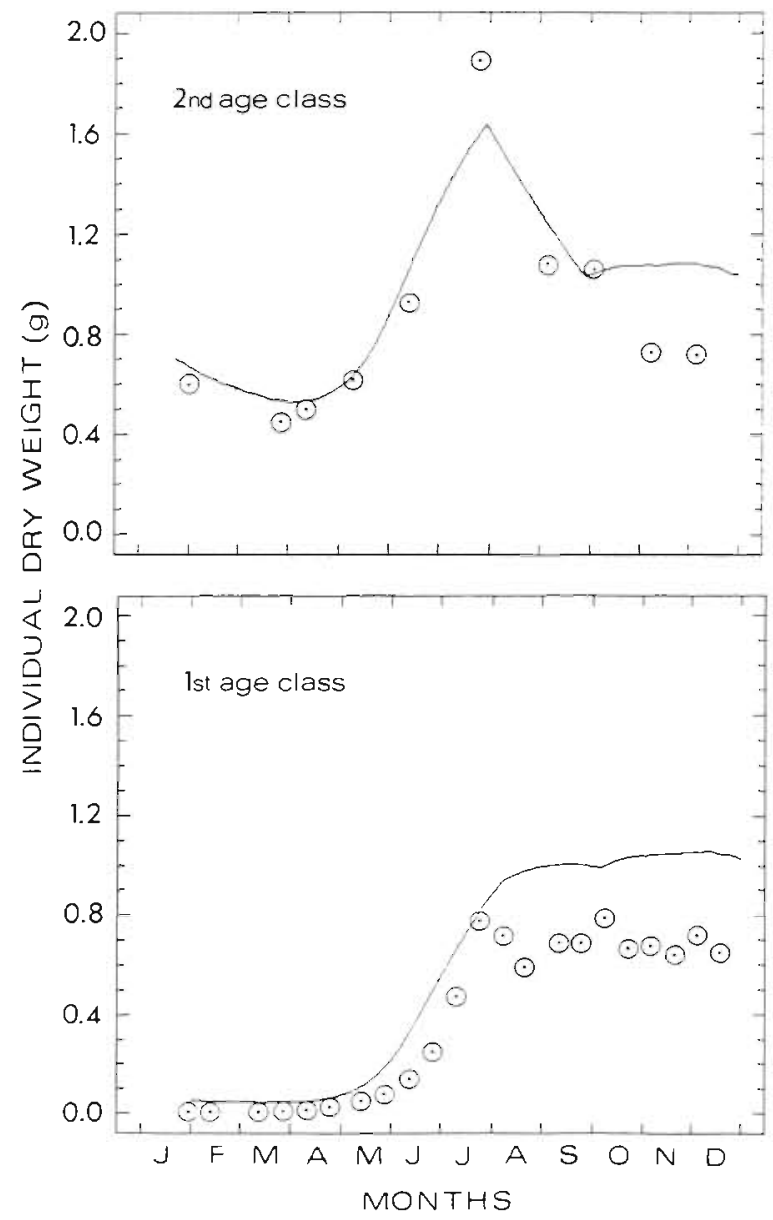

Fig. 7. Simulated $(-)$ and observed $(\odot)$ individual growth of oysters in Box 14

\section{DISCUSSION}

The fact that the model reproduces the magnitude and the shape of distribution of the various constituent parameters indicates that relevant processes are accounted for ( $O^{\prime}$ Connor 1981). Consequently, this suggests that the present model may be used to make assumptions about the factors that regulate carrying capacity of the shellfish system.

The results of the sensitivity analysis can be interpreted in terms of dynamic food supply. The northsouth gradient of growth sensitivity in response to variation of stock reveals the overriding effect of hydrodynamic processes on the renewal of food within the bay. Production of phytoplankton in the shellfish area is not actually sufficient to balance the depletion induced by the feeding activity of oysters. The flushing time of water masses and the available light energy in the water column are found to be 2 factors that prevent phytoplankton from thriving in the bay. As shown by

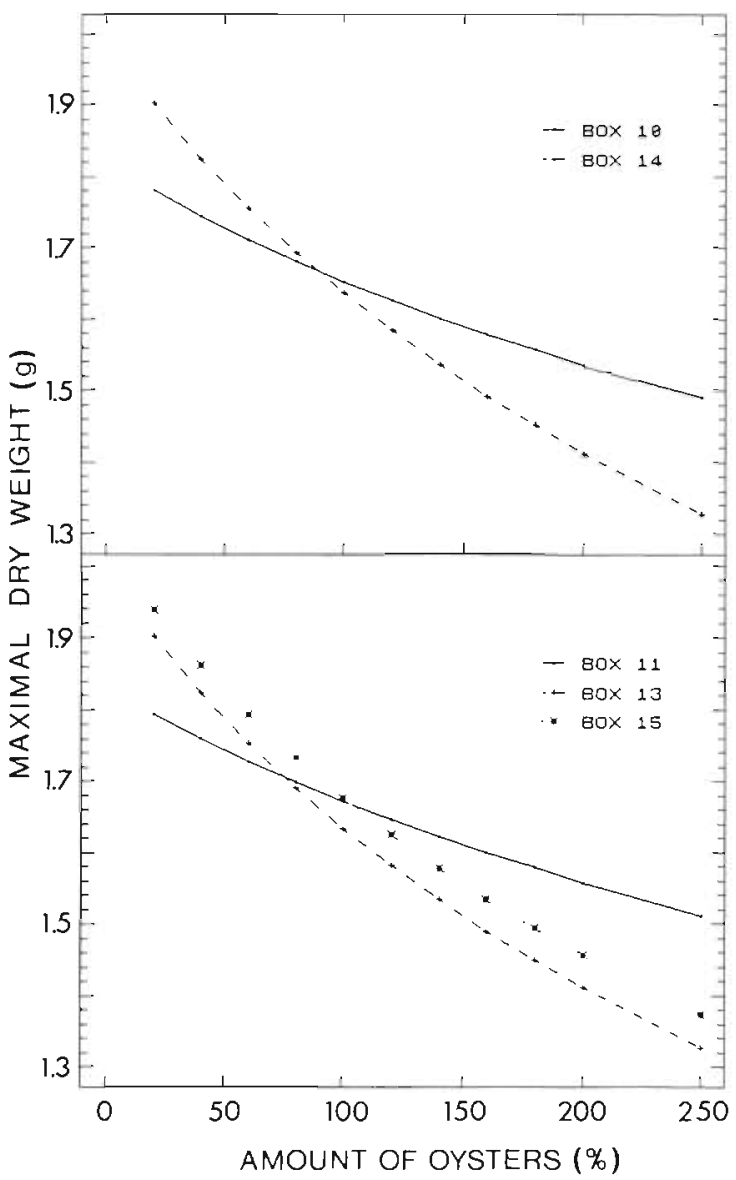

Fig. 8. Sensitivity of oyster individual growth to oyster stock. The stock is expressed as a percentage of the nominal value

calculations for different boxes (Table 4), the flushing time of the water masses is generally shorter than the doubling time of phytoplankton (between 0.5 and $9 \mathrm{~d}$ ), preventing significant accumulation of phytoplanktonic new material within the box volume (Officer 1980). The interaction between flushing time and biological processes has been previously described by Es \& Ruardij (1982) and Helder et al. (1983), by integrating this time scale in the computation of oxygen consumption and nutrient production. The overriding effect of light limitation on photosynthesis when compared to nitrate limitation is clearly illustrated by the growth limitation curves displayed in Fig. 9. In Box 8 the greater water depth (see Table 4) together with the assumption of vertical homogeneity of the water column explain the strong limitation of phytoplanktonic growth by light energy. In contrast, in Boxes 6 and 14, as shown by the spring/neap tidal variability of light limitation, the level of mineral seston controls light limitation. 
Table 4. Physical and biological characteristics of the boxes in Marennes-Oléron Bay

\begin{tabular}{|lccccccc}
\hline & Box 6 & Box 8 & Box 10 & Box 11 & Box 13 & Box 14 & Box 15 \\
\hline Volume $\left(\times 10^{6} \mathrm{~m}^{3}\right)$ & 26.55 & 149.14 & 110.88 & 79.78 & 4.46 & 79.10 & 93.43 \\
Flushing time, min.-max. (d) & $0.4-0.71$ & $0.22-0.52$ & $0.24-0.60$ & $0.15-0.41$ & $0.16-0.36$ & $0.25-0.49$ & $0.36-0.52$ \\
Number of oysters in: & 0 & 0 & 1.27 & 314.77 & 8.51 & 306.55 & 124.12 \\
First age class $\left(\times 10^{6}\right)$ & 0 & 0 & 15.81 & 220.03 & 17.69 & 626.94 & 496.49 \\
Second age class $\left(\times 10^{6}\right)$ & 2.53 & 11.32 & 5.38 & 4.31 & 0.92 & 2.65 & 3.57 \\
Average depth $(\mathrm{m})$ & & & & & & \\
\hline
\end{tabular}

The present model differs from the model developed by Bacher (1989) mainly by including phytoplanktonic growth. The sensitivity analysis computed by the 2 models shows 2 major differences. First, the range of 'stock vs growth' curves computed for the different boxes is narrower when predicted by our model. From this observation, it can be asserted that the food supply arising from primary production partly balances the north-south depletion due to oyster feeding activity and subsequently smoothes the spatial heterogeneity of trophic capacity. Second, Bacher's model does not predict a change in the spatial gradient of oyster growth performance. In our model, oyster growth in Boxes 13,14 and 15 is better than in Boxes 10 and 11 in the case of low stock levels, whereas it is the contrary when stock levels are high. This may be due to the lower total filtering action of oysters situated northward when stock levels are low, which allows the local production of phytoplankton to be sufficient for oyster production.

Considering the sensitivity of the carrying capacity to primary production, the present model suggests, especially for large variations of oyster stock, that more confidence can be placed in predictions when the nutrient/phytoplankton system is simulated.

In order to further illustrate the impact of oysters on food supply, the annual distribution of phytoplankton biomass computed for 2 levels of stock is plotted in Fig. 10. The computed decrease in phytoplankton biomass when the number of oysters is trebled (i.e. from $50 \%$ to $150 \%$ of the present value) indicates that molluscs do not strongly control phytoplankton biomass in Marennes-Oléron, which is contrary to what was observed in San Francisco Bay (Cloern 1982) or in the Oostershelde (Smaal et al. 1986). This model result can probably be related to the flushing time within the bay. The low residence time, which ensures rapid renewal of the food supply, is responsible for the high carrying capacity predicted by the model.

The appraisal of the shellfish system as suggested by the above interpretations of the model results naturally depends on model reliability. Even if the present model has produced realistic trends of the evolution of several ecosystem components, the comparisons between model and data have also shown significant discrepancies. The explanatory and predictive value of the model may be assessed by analysing its various faults (Baretta \& Ruardij 1988).

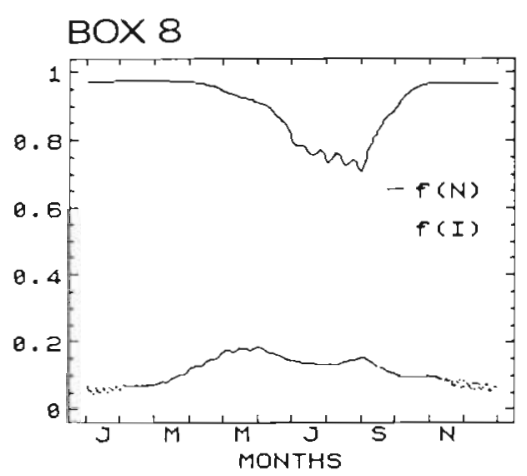

$\mathrm{BO} \times 6$

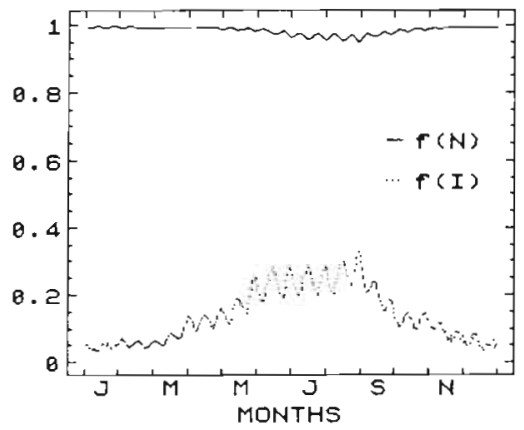

$\mathrm{BO} \times 14$

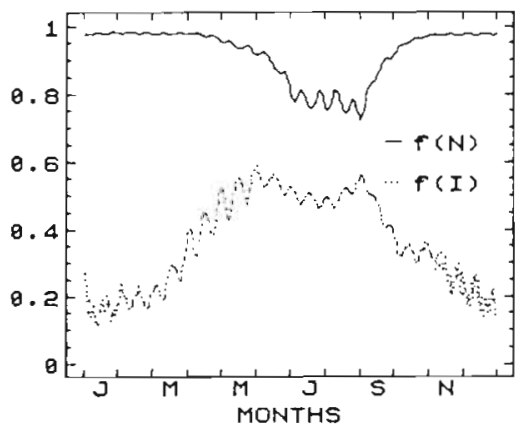

Fig. 9. Computed (dimensionless) limitation factors of phytoplanktonic growth by light availability and nutrient concentration 
Spring/neap tidal variability of particulate matter is one of the weakest points of the present model. The simulated spring/neap tidal variability is actually due to differences in mixing between ocean and bay waters during neap and spring tide (Raillard 1991). However, considering the shallow depth and the vigorous hydrodynamic regime of the bay, vertical exchanges between sediment and water may also control the concentration of particulate matter. During neap tide, the concentration would be increased because of low current speed, but during spring tide the high current velocity would enhance resuspension of particulate matter.

From a modelling point of view, the deposition of particulate matter would not largely affect the computed food supply. Even if the process can be supposed to increase the residence time of particulate matter in the bay (and hence the food supply), it also reduces, in compensation, the period of food availability for oysters (the deposited food is not available for oysters). However, the carrying capacity of the bay could be differently evaluated if the food is in fact fluctuating as observed. Being generally non-linear, the mathematical expressions describing biological processes are
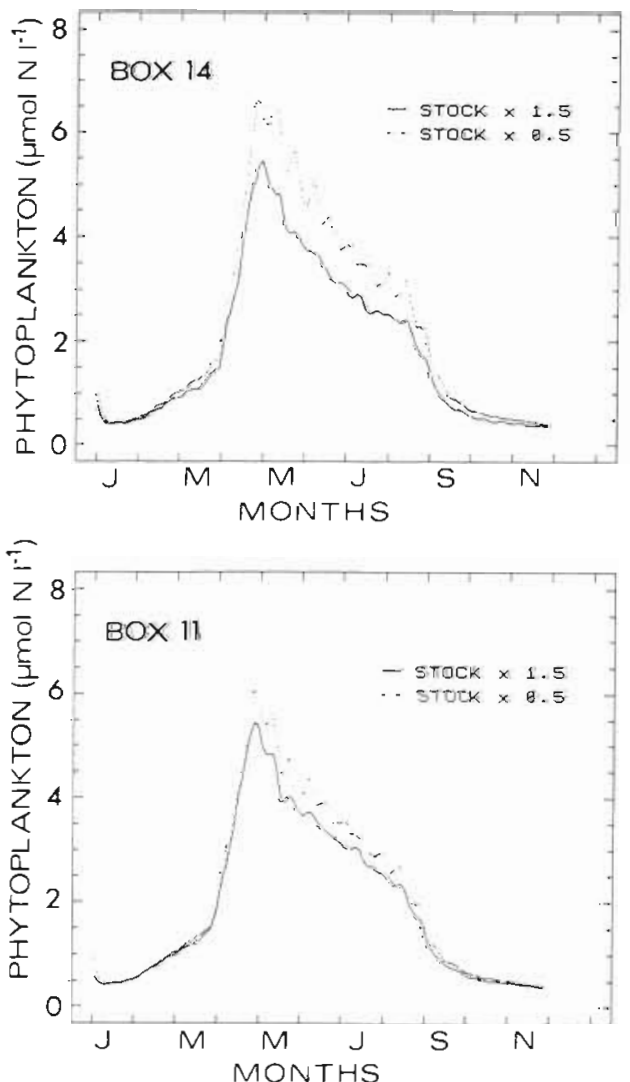

Fig. 10. Temporal distribution of phytoplankton biomass for 2 levels of oyster stock sensitive to the variability of the driving parameters, even if the seasonal trend of the evolution is conserved. Furthermore, the influence of the vertical exchanges on suspended matter concentration is dependent on both the bathymetry and the current velocity within the bay. This probably leads to increased spatial heterogeneity of food concentration. We suggest that a more realistic picture of the physical and biological dynamics of the shellfish system could be achieved with an explicit simulation of the erosion and sedimentation processes.

The overall underestimation of phytoplankton biomass in the estuary (Box 6) can be explained by a lack of precision in the modelling of phytoplankton dynamics. Following Ravail et al. (1988), it can be assumed that (1) local primary production is actually enhanced by a specific species of phytoplankton that is well adapted to low light levels, and (2) inputs of terrigenous chlorophyll coming from the River Charente account for a non-negligible part of the phytoplankton biomass within the estuary. Nevertheless, considering that the Box 6 has a relatively small volume (Table 4) and that it does not contain oysters, it can be assumed that the incorrect estimation of the phytoplankton biomass in this box does not severely bias the overall prediction of the carrying capacity.

Overestimation of the spatial homogeneity of the distribution of the pelagic components also has a numerical origin. The first upward differencing scheme used here to solve the transport equation has the advantage of being explicit, forward in time, and therefore very fast. However, the algorithm is accurate only to the first order in time and space and, therefore, produces a strong numerical diffusion (Bott 1989), resulting in both overestimation of the water mixing between the different boxes and underestimation of the flushing time (Bird \& Hall 1988). The effective interactions between biological and physical processes are likely to be biased by such a numerical defect. Globally, the reduction of the flushing time tends to cause an underestimation of the influence of biological processes on the temporal evolution of pelagic variables within the bay. However, the 2 processes that control food supply, i.e. primary production and physical transport, are inversely influenced by the flushing time: the former is decreased when flushing time increases, whereas the latter is increased. Since the 2 effects can balance each other, the underestimation of flushing time may have little influence on the estimation of the bay's carrying capacity. Nevertheless, the numerical scheme also masks the spatial heterogeneity of the system and subsequently limits its validity.

In order to reduce numerical diffusion, Bird \& Hall (1988) and Shanahan \& Harleman (1984) suggest optimizing the 'current number' by adjusting space and 
time steps of the system. But the differences between the volumes of the boxes make this solution inapplicable to the present case. It is also possible to integrate the biological laws inside the spatial and temporal structure of the hydrodynamic models. In such models, advection and dispersion of suspended matter are computed by efficient algorithms that significantly reduce numerical dispersion (Bott 1989). Even if one ignores the computation cost of such an approach, we think there are 2 other reasons to be doubtful about its relevance: (1) the validity of the biological laws is not independent of the spatial and temporal context; (2) the combination of the non-linearities of both hydrodynamic and biological models could lead to a numerically very unstable and consequently unreliable system. We think that even if the box structure of the ecosystem models drives to some extent the responses of the model, it is nevertheless a framework that confers robustness to model predictions.

\section{CONCLUSION}

The model of the Marennes-Oléron shellfish system accurately reproduces some of the biological and physical features of the bay. According to model results, carrying capacity is sensitive to spatial distribution and stock levels of oysters. Because of the short residence time of water in the bay, hydrodynamic regime is a determining factor that controls the carrying capacity of the system. The model could be significantly improved by considering vertical exchanges (in terms of sedimentation and erosion) in the computation of food transport, and by reducing the numerical dispersion of the advection/dispersion scheme.

Acknowledgements. We are indebted to Dr Robert Willow's for suggesting some improvements in the English text.

\section{LITERATURE CITED}

Anonymous (1979). Dispersion de la pollution dans les pertuis charentais. Rapport technique général. Laboratoire Central Hydraulique de France, Maison Alfort

Bacher, C. (1989). Capacité trophique du bassin de Marennes-Oléron: couplage d'un modèle de transport particulaire et d'un modèle de croissance de l'huitre Crassostrea gigas. Aquat. Living Resour. 2: 199-214

Bacher, C., Baud, J. P., Deslous-Paoli, J. M., Dreno, J. P., Héral, M., Maurer, D., Prou, J. (1986). A methodology for the stocks assessments of cultivated oyster along the French Atlantic coasts. J. Cons. int. Explor. Mer, CM 1986/K: 36: $1-14$

Baretta, J. W., Ruardij, P. (1988). Tidal flat estuaries: simulation and analysis of the Ems estuary. Ecological studies 71 Springer-Verlag, Berlin

Bayne, B. L., Widdows, J., Thompson, R. J. (1976). Physiological integrations. In: Bayne, B. L. (ed.) Marine mussels: their ecology and physiology. IBP No. 10, Cambridge Univ. Press, Cambridge, p. 261-291

Bird, S., Hall, R. (1988\}. Coupling hydrodynamics to a multiplebox water quality model. Tech. Rep. EL-88-7, Waterways Experiment Station, Corps of Engineers, Vicksburg, MS

Bott, A. (1989). A positive definite advection scheme obtained by nonlinear renormalization of the advective fluxes. Mon. Weather Rev. 117-1006-1015

Brock, T D. (1981). Calculating solar radiation for ecological studies. Ecol. Model. 14: 1-19

Carvet, C. E. A., Mallet, A. L. (1990). Estimating the carrying capacity of a coastal inlet for mussel culture. Aquaculture 88: $39-53$

Chen, C. W., Smith, D. J. (1979). Preliminary insight into a three-dimensionnal ecological-hydrodynamic model. In: Scavia, D., Robertson, A. (eds.) Perspectives on lake ecosystem modelling. Ann Arbor Publ. Co., Ann Arbor, MI, p. $249-279$

Cloern, J. E. (1982). Does the benthos control phytoplankton biomass in south San Francisco Bay? Mar. Ecol. Prog. Ser. 9: $191-202$

Cloern, J. E. (1987). Turbidity as a control on phytoplankton biomass in south San Francisco Bay. Cont. Shelf Res. 7 $1367-1381$

Corner, E. D. S., Cowey, C. B., Marshall, S. M. (1967). On the nutrition and metabolism of zooplankton. V: Feeding efficiency of Calanus finmarchicus. J. mar. biol. Ass. U.K. 47 $259-270$

Dechambenoy, C., Pontier, L., Siriou, F., Vouve, J. (1977). Apport de la thermographie infra-rouge aéroportée à la connaissance de la dynamique superficielle des estuaires (système Charente-Seudre-Anse de l'Aiguillon). C.r. Acad. Sci. Paris 284: 1269-1272

Eppley, R. W., Holmes, R. W., Strickland, J. D. H. (1967) Sinking rate of marine phytoplankton measured with a fluorimeter. J. exp. mar. Biol. Ecol. 1: 191-208

Es, F. B. van, Ruardij, P. (1982). The use of a model to assess factors affecting the oxygen balance in the water of the Dollard. Neth. J. Sea Res. 15(3/4): 313-330

Frost, B. W. (1972). Effect of size and concentration of food particles on the feeding behaviour of the marine planktonic copepod Calanus pacificus. Limnol. Oceanogr. 17: $805-815$

Gaudy, R. (1974). Feeding four species of copepods under experimental conditions. Mar. Biol. 25: 125-141

Helder, W., De Vries, R. T. P., Rutgers van der Loeff, M. M. (1983). Behaviour of nitrogen nutrients and silica in the Ems-Dollard estuary. Can. J. Fish. Aquat. Sci. 40 (Suppl. 1): $188-200$

Héral, M., Deslous-Paoli, J.-M., Prou, J. (1986). Dynamique des productions et des biomasses des huitres creuses cultivées (Crassostrea gigas et Crassostrea angulata) dans le bassin de Marennes-Oléron depuis un siècle. Note au CIEM, CM 1986/F: 41.1-23

Héral, M., Deslous-Paoli, J.-M., Prou, J. (1988). Approche de la capacité trophique d'un écosystème. Note au CIEM, CM 1988/K: 22: 1-11

Héral, M., Deslous-Paoli, J. M., Sornin, J. M. (1983a). Transfert énergétique entre l'huître $C$. gigas et la nourriture potentielle dans un bassin ostréicole: premières approches. Océanis 9:169-194

Héral, M., Razet, D., Deslous-Paoli, J.-M., Berthomé, J. P., Garnier, J. (1983b). Caractéristiques saisonnières de l'hydrobiologie du complexe estuarien de MarennesOléron (France). Rev. Trav. Inst. Pêch. marit. 46: 97-119

Incze, L. S., Lutz, R. A., True, E. (1981). Modelling carrying capacity for bivalve molluscs in open, suspended-culture 
systems. J. World Maricult. Soc. 12(1): 143-155

Kautsky, N., Evans, S. E. (1987). Role of biodeposition by Mytilus edulis in the circulation of matter and nutrients in a Baltic coastal ecosystem. Mar. Ecol. Prog. Ser. 5: 291-296

Lindeboom, H. J., Van Raaphorst, W., Ridderinkhof, H., Van der Veer, H. W. (1988). Ecosystem model of the western Wadden sea: a summary. NIOZ Rapport 1988-11, NIOZ, Texel

Newell, I. E., Jordan, S. J. (1983). Preferential ingestion of organic material by the American oyster Crassostrea virginica. Mar. Ecol. Prog. Ser.13: 47-53

O'Connor, D. J. (1981). Modelling of eutrophication in estuaries. In: Neilson, B. S., Cronin, L. E. (eds.) Estuaries and nutrients. Humana Press, Clifton, NJ, p. 183-223

Officer, C. B. (1980). Box model revisited. In: Hamilton, P., MacDonald, K. B. (eds.) Estuarine and wetland processes. Plenum Publishing Corp., New York, p. 65-114

Parsons, T. R., Lebrasseur, R. J., Fulton, J. D. (1967). Some observations on dependance of zooplankton grazing on the cell size and concentration of phytoplankton blooms. J. Oceanogr. Soc. Japan 23: 10-17

Radford, P. J., Joint, I. R. (1980). The application of an ecosystem model to the Bristol Channel and Severn estuary. J. Inst. Wat Pollut. Control 2: 244-254

Raillard, O. (1991). Etude des interactions entre les processus physiques et biologiques intervenant dans la production de l'huitre japonaise Crassostrea gigas du bassin de Marennes-Oléron: essais de modélisation. Thèse doct Océanographie, Univ. Paris VI

This article was submitted to the editor
Raillard, O., Deslous-Paoli, J. M., Héral, M., Razet, D. (1993). Modélisation du comportement nutritionnel de Crassostrea gigas dans le bassin de Marennes-Oléron. Oceanol. Acta 16: 73-82

Ravail, B., Héral, M., Maestrini, S., Robert, J. M. (1988). Incidence du débit de la Charente sur la capacité biotique du bassin ostréicole de Marennes-Oléron. J. Rech. océanogr. $13(1-2): 48-52$

Rosenberg, R, Loo, L. O. (1983). Energy-flow in a Mytilus edulis culture in western Sweden. Aquaculture 35: $151-161$

Shanahan, P. Harleman, D. R. F. (1984). Transport in lake water quality modeling. J environ. Eng. 110(1): 42-57

Smaal, A. C., Verhagen, J. H. G., Coosen, J., Haas, H. A. (1986). Interaction between seston quantity and quality and benthic suspension feeders in the Oostershelde. The Netherlands. Ophelia 26: 385-399

Soniat, T. M., Ray, S. M., Jeffrey, L. M. (1984). Components of the seston and possible available food for oysters in Galveston Bay, Texas. Contrib, mar. Sci. 27: 127-141

Sornin, J. M. (1981). Processus sédimentaires et biodéposition liés à différents modes de conchyliculture. Baie de Cancale, Anse de l'Aiguilion et Bassin de Marennes-Oléron. Thèse doct., Univ. de Nantes

Steele, J. M. (1962). Environmental control of photosynthesis in the sea. Limnol. Oceanogr. 7:137-150

Wildish, D. B., Kristmanson D. D. (1979). Tidal energy and sublittoral macrobenthic animals in estuaries. J. Fish. Res. Bd Can. 36: 1197-1206

Manuscript first received: July 23, 1993

Revised version accepted: August 19, 1994 